\title{
Critical issues of intellectual capital theory in transitional countries
}

\author{
L. Statsenko • L. Bozhko • G. Prause ・ V. Ireland
}

Published online: 18 December 2013

(C) International Network of Business and Management 2013

\begin{abstract}
Since the independence of Kazakhstan over 20 years ago a large number of political reforms took place to modernize the institutional structures and to establish a modern business environment for facilitating foreign investments and privatization programs. Between 2001 and 2008 the GDP growth rates were over $10 \%$ per year and even after the crisis of 2008 the Kazakh growth rates were positive in contrast with that of Commonwealth of Independent States neighbors so that in 2011 the World Economic Forum determined Kazakhstan's economy as transitional from factor driven to efficiency driven. Despite Kazakhstan's big steps ahead in the improvements of the macro-economic environment the most problematic areas are related to innovation and business sophistication. So innovation capacity and intellectual capital are still low ranked, i.e. technical and managerial skill, research capacity and effective university-industry cooperation are only weakly developed. The purpose of this paper is application of intellectual capital (IC) approach for developing a strategic management model as a means of organizational transformation within the context of transitional economy at Kazakh mining company. The Kazakh government is committed to tackling the difficulties of "radical" change by putting in practice new economic and political reforms; for innovative and creative thinking, however, such change is challenging. The current perception of IC as an intangible asset by senior and middle management of the Kazakh mining company is explored and a model of strategic management for company's transformation from a "mechanistic" to a "learning" organization is examined in a case study.
\end{abstract}

\footnotetext{
L. Statsenko · L. Bozhko

Rudny Industrial Institute, Rudny, Kazakhstan

G. Prause $(\bowtie)$

Tallinn University of Technology, Tallinn, Estonia

e-mail: gunnar.prause@ttu.ee

V. Ireland

University of Adelaide, Adelaide, Australia
} 
Keywords Transitional economy $\cdot$ Intellectual capital theory $\cdot$ Mining organization $\cdot$ Kazakhstan

\section{Introduction}

Kazakhstan, as a former Soviet Union country, has been considered emerging economy where local companies develop their strategies based on the principles of survival and development in emerging economy. The current perception of intellectual capital as an intangible asset in Kazakh companies is still rarely found as well as the development of strategic management models as a means of organizational transformation.

The paper highlights in form of a case study, a change management project within large Northern Kazakh mining company which was historically determined by hierarchical and functional management structures perfectly fitting to a definition of a "mechanistic" organization. The project applied an intellectual capital (IC) approach and explored a model of strategic management for company's transformation from a "mechanistic" to a "learning" organization.

This case study shows that the implementation of strategic oriented learning organization model within the context of a traditional post-soviet company can be successfully realized. The paper also provides evidence that despite the still weak aspect of IC in today's Kazakh companies the transformation of a "mechanistic" organization into a "learning" one is a feasible task.

\section{Kazakhstan: political and economic background}

In the 20 years since independence, Kazakhstan has experienced a remarkable economic and political transformation, moving towards achievement of national economic growth, financial, and social stability. From the mid-1990s, Kazakhstan commenced a number of political and economic reforms, such as price liberalization, recognition of private property rights, establishment of a business environment conductive to foreign investments, and privatization program (Bhuiyan 2011; Knox 2008). The political reforms took place through changes to the constitution and programs of public service modernization.

In 2012, the World Economic Forum (WEF) determined that Kazakhstan's economy was transitional, moving from efficiency driven to innovation driven. In spite of the fact that the "basic requirements" and "efficiency enhancers" indexes were 47 and 56 out of 144, respectively, "innovation and sophistication" index remains quite low-104 out of 144 (World Economic Forum and 2013).

In 2006, Kazakhstan aimed to enter into the top 50 economically competitive countries of the world and achieved its goal, moving to 50th position out of 125 countries in the Global Competitiveness Report. Over next 5 years, Kazakhstan's rank had gradually fallen to 72 out of 142 in the year 2011-2012. But in 2012-2013, it raised again up to 51st position. The next goal set by the President Nazarbaev is to reach 30th position in Global competitiveness rating by 2050.

Currently, Kazakhstan's current key competitive advantages are its macroeconomic environment, strongly influenced by low inflation, which is ranked 16th, and 
technological readiness, where it advances from 87th to 55th. Despite the progress achieved, the areas of greatest concern for the government are the business sophistication (99th) and innovation (103rd). The primary cause of the low ranking is low business sophistication, which is a legacy of previously planned economies that focused on narrow parts of the value chain, and lacked marketing and other capabilities related to success in a modern market (World Economic Forum 2013; Andekina and Medeni 2013).

The government of Kazakhstan has made significant efforts to establish a number of industrial programs, such as the High-speed Industry and Innovation Development for 2010-2014 program and Performance 2020, aimed at forcing the transition to an efficiency driven economy by providing both legislation and financial incentives aimed at supporting organizational cultural change and business innovation. The program also encourages enterprises to develop sophisticated technologies and business management methods in all industrial sectors of the economy.

However, Kazakhstan ranks only 101 of 142 in the capacity to innovate as of 2013 (World Economic Forum 2012-2013). Technical and managerial skill shortage and innovation capacity are hampered by the low quality of management schools (103th) and research institutions (108th), as well as the effectiveness of university-industry collaboration in R\&D (90th).

Analysis based upon World Competitiveness Report performed by Hoskisson et al. (2013) categorized Kazakhstan economy as "mid-range economy" with middevelopment of institutions as well as infrastructure and factor markets (Hoskisson et al. 2013).

Today one can fairly assert that Kazakhstan has passed the initial phase of the transition from a planned to a market-based economy (Bhuiyan 2011). However, Kazakh companies need an approach to leverage innovations within their organizations (Dosmanbetova 2013; Statsenko et al. 2013; Tsekhovoy and Statsenko 2010; Zabortseva 2009), and this is effectively the task of managing their intellectual capital.

\section{Theoretical background}

The relation between resource based view and intellectual capital theory

The resource-based view (RBV) of a firm has been developed for over 30 years. During this time, it has been both widely taken up and subjected to criticism. The core idea of RBV is that if a firm is to achieve a state of competitive advantage and positive organizational outcomes it must acquire and control valuable, rare, inimitable, non-substitutable resources, and capabilities both tangible and intangible, plus have the organization in place that can absorb and apply them (Barney 2001).

To transform a short-run competitive advantage into a sustained competitive advantage requires that these resources are heterogeneous in nature and not perfectly mobile (Barney 2001). Thus, the resource and value, and the narrow conceptualization of a firm's competitive advantage are the basic concepts of the RBV (Kraaijenbrink 2009). Within the RBV, the strategic reference point shifted 
from the external to the internal. As opposed to the industry-based view, proposed by Porter (1981), the firm itself became the main subject of investigation. In the long run, competitiveness is derived from the ability to build a Core Competence at lower cost and more speedily than competitors. This proposition is shared by several related analyses including knowledge-based view (KBV).

Starting in the 1980s, RBV has developed and gained influence in the strategic management and international business literature. Wernerfelt (1984) was the first, who looked at firms in terms of their resources rather than in terms of their products. Later, valuable contributions to theory for developed markets were made by a number of scholars (Barney 2001; Peteraf 1993; Conner and Prahalad 1996; Helfat and Peteraf 2003; Amit and Schoemaker 1993).

Research on emerging economies has broadened and deepened the RBV (Martínde Castro et al. 2013; Hoskisson et al. 2013).

However, being widely adopted by strategic researches, some critics of its basic foundations exist (Kraaijenbrink 2009; Thorpe et al. 2005; Priem et al. 2013). For example, Kraaijenbrink (2009) claims that placing its focus on the resource as the firm's basic component and its narrow view of firms as a bundle of these resources, the RBV is explicitly reductionist and stands against holistic theories. Thorpe et al. (2005) considers it unsuitable to explain the emergence of a competitive advantage in dynamic markets. Priem et al. (2013) raise questions about RBV legitimacy as a theory as it is extremely difficult to parameterize and to test empirically its basic axioms without measuring intangible assets in some detail.

The KBV as an extension of RBV focuses on the value of intangible assets and suggests that knowledge is critical to a firm's long-term success. The current evolving economy characterized by the new technologies, the globalization, and an ever-increasing emphasis on intangible services (Barney 2001; Grant 1996). Taking this perspective, performance differs between organizations by addressing asymmetries in knowledge as a foundation (Amit and Schoemaker 1993; Conner and Prahalad 1996). Thus, firm's performance is significantly enhanced when the strategy includes acquiring and managing knowledge-based resources by accumulating and processing it to enable organizational learning. KBV explains the existence, growth, evolution, and internal organization of the firm taking as a key point available knowledge. According to KBV, strategic decisions of local firms are shaped by the cognitive capabilities of their managers. The propensity of firms to explore and acquire new knowledge is influenced by the exposure to diverse external sources of knowledge. Quast (2012) suggests three main reasons for efficient management of knowledge of the organization. First of all, it helps to strengthen decision-making capabilities. Explicit database provides managers with information for high quality decisions. It means that knowledge management facilitates more informed decisions. Overall, these works show that firms that build their strategies on path dependent, causally ambiguous, socially complex, and intangible assets outperform firms that build their strategies only on tangible assets (Barney 2001).

Another powerful stream that emerged in the strategic literature was the perspective of intellectual capital, or the efforts to identify and measure the assets, resources, and capabilities of intangible nature, which are a source of competitive 
advantage of the firm (Martín-de Castro et al. 2013). In the late 1990s, the need for systematic measurement, management, and representation of intangible assets were articulated in the Western literature. Since then, knowledge has been considered a key valuable resource for organizations; and the substantial literature on IC measurement, management, and reporting has emerged (Bukh and Johanson 2003; Edvinsson and Malone 1997; Roos et al. 2012; Sveiby 2003) including a number of IC frameworks (Sveiby 2003).

IC is considered to be the key driver of innovation capacity (Bhuiyan 2011; Bukh and Johanson 2003; Cabrita and Bontis 2008; Roos et al. 2012; Sveiby 2003), which have a strong impact on productivity of firms (Sveiby 2003). As innovative firms are financially more robust and generate higher employment; management of IC is a key determinant of future firm performance.

The concept of IC was developed to evaluate and manage organizational knowledge (Petty and Guthrie 2000; Roos et al. 2012; Stewart and Ruckdeschel 1998; Sveiby 2003). Edvinsson and Malone (1997) broadly defined IC as“...the sum of a company's intangible resources (including knowledge, technology, brand reputation)". However, recently scholars have shown (Bukh and Johanson 2003; Roos et al. 2012) that IC includes both tangible and intangible components. One current definition of IC is “... non-monetary and non-physical resources that are fully or partly controlled by the organization and that contribute to the organization value creation..." (Roos et al. 2012). IC is considered to be tri-partite, including relational, organizational (structural), and human capital.

Kazakhstani firms strategies

Since past decade Kazakhstan's economy has been considered emerging (Hoskisson et al. 2013; Bruton et al. 2008; Kholjigitov 2013; Knoop 2013). Kazakhstan, as a former Soviet Union country with low institutional development and high infrastructure and factor development is considered as mid-range emerging economy (Hoskisson et al. 2013). Although taking into consideration social and political peculiarities of the local market, the Kazakhstani firms develop their strategies based on the principles of survival and development in emerging economy.

The radical changes in economic and political situation as well as strategic course of innovative development for the State had forced newly formed companies to seek ways to survive and prosper in the current market conditions. Domestic firms in Kazakhstan face rapid political, economic, technological, and institutional changes. These environmental uncertainties create the necessity for upgrading and reconfiguring the existing resources and capabilities. The Kazakhstani firms facing the same situation as many others at post-soviet space took different approaches to survive and compete. In the global market economy where the prices of goods and services are determined in a free price system force companies to take managerial decisions not only on what to produce, but also how to produce it in more efficient manner. This is totally contrasted with the state-directed or planned economy with the state owned enterprises and the prices being set by the government when business needs not to be sophisticate as it was compensated by government for loss. 
The standpoint of the work (Medved et al. 2011), which discusses the issues of transition of managerial approaches from planned economy methods to market based principles in the company's previously being state owned, is based on belief that this transition is a multidimensional task. It must include the following dimensions: legal—changing pattern of ownership, financial-capital restructuring, product and service portfolio restructuring, organizational restructuring, and developing new operational methods.

While most Kazakh companies coped with the first three issues during past 10 years the last one is still being a challenge. This issue is connected with the fact that while legal and financial restructuring requires government and company's board decisions made at higher management levels, the organizational and operational restructuring involving a large number of employees require introduction of new methods and technologies. Here, it is really important to mention that none of these improvements would work properly without changing people's mind at all organizational levels and building new forms of relationships, including organizational restructuring and changing decision making patterns. Moreover, according to Savitt (1998) this issue is the dimension where strategy should be developed and implemented.

Some works devoted to organizational changes (Beer and Mike 2013; Briner et al. 2012; Knox 2008) provide frameworks for types and strategies of organizational changes. For example, Knox (2008) discussing the challenges of management changes in Kazakhstan, consider organizational "archetypes", which include the formal structure of the organization; systems of decision making; underlying interpretive schemas (core values, beliefs, and ideology), and argue, that changes should occur simultaneously in all three dimensions. From this perspective, we could assert that the organizational changes in Kazakh companies are distorted toward the first objective of formal restructuring, while the last two still require measures taken. Non-profit organization's strategy was studied by Kabdiyeva (2013), Alymkulova and Seipulnik (2005). The ways of promoting innovations and compensating for missing elements in the technology-based infrastructure and environment through techno parks establishment in Kazakhstan were discussed by Radosevic and Myrzakhmet (2009), Bogko (2012). Ismail et al. (2013) studied the relationship among managerial ties, strategic initiatives, and firm performance in emerging economies, including Kazakhstan.

While, a wide body of the literature supported by successful practical examples has been presented to help western companies embrace the complex process of managing their IC, not many studies have been conducted for emerging and developing economies (Kiessling et al. 2009; Ireland and Webb 2009; Andekina and Medeni 2013; Bhasin 2012). Even less evidence is found for the Commonwealth of Independent States (CIS) region. The focus of the previous Russian publications concerned with knowledge management and intellectual resources theory has been developed through the perception of knowledge as the input for research and development achievements. Thus, the object of research was to articulate the "IC scientific-industrial progress" chain as an "input-output" model, whereas the procedure of transformation-the "how", was neglected. These models included: communication aspects, which covered the processes of information and knowledge 
transfer, mainly through technical decisions of information technologies; financial aspects, which accounted investments in science; and legal aspects, which encompassed the issues related to the rights of intellectual property. Therefore, such models had obvious drawbacks as they: represented a static and deterministic picture of knowledge assets; put emphasis on quantitative rather than qualitative aspect of knowledge; did not take into consideration intangible attributes of the IC; and did not provide obvious linkage between their components.

The current research shows that in spite of the fact that CIS researchers currently articulate the IC role in an organizational development process (Illyashenko and Shypulina 2013; Andreeva and Kianto 2012; Kianto et al. 2013; Andekina and Medeni 2013), and the practical evidence shows that it is in an infancy stage.

Not much research found on application of KBV or IC to evaluate and manage intangible assets and knowledge management process in Kazakh companies. Griffith et al. (2001) studied the strategy of international joint ventures (IJV) in terms of the issues of knowledge transfer between foreign and local partners in Kazakhstan and indicate that transfer of knowledge, which is considered a resource-based asset is a key for IJV success. Andekina and Medeni (2013) explore the efficiency and importance of knowledge management for business entities, and claim to provide benchmark of best practices for Kazakhstan, providing a model of a knowledge-based organization. Authors also highlight that if knowledge is not saved, recorded, and shared firms are more likely not to achieve their targeted productivity, because knowledge in all firms is peoplebased. Nevertheless, in some entities there is a scarcity of concepts and tools for managing these intangible assets in a systemic and an efficient way (Andekina and Medeni 2013). Dyker (2005) studying dynamic competitiveness of Kazakh firms found that historically conditioned tendency to isolation weaken this capability and excludes networking as it operates in the advanced industrial economies. In spite of the fact that the role of human capital is generally recognized in Kazakhstani companies, public policy in this area is perceived as being highly ineffective, in a situation where the companies themselves do not have sufficient resources to fund all the training they need.

Thus, recognizing the need for evaluating and managing intangible assets of the mining company at this stage of transition, the use of IC theory was chosen to facilitate this.

\section{Methodology}

This research was organized as a single, holistic, instrumental case study aimed at investigating how the implementation of the IC approach influences strategic management model in the organization of transitional economy. This question is based upon the investigation of following issues:

1. What is the current perception of IC's as a mean for competitive advantage by different levels of management at the targeted company? 
2. How has the framework for evaluation and measurement of intangible assets changed through and after organizational learning process?

3. How this new framework affects the organizational performance?

The case study approach was applied as a useful research method to explore and understand the phenomena in-depth through examination of the context, the issues, the data analysis, and the "lessons learned" (Creswell 2007; Guba and Lincoln 1994). Multiple sources of information were used to provide the detailed picture of this particular case.

The data collection based on structured in-depth interviews with members of the company management on different hierarchy levels. Parallel in workshops, the existing performance measurement systems were analyzed and further developed to a balanced scorecard concept stressing intellectual capital aspects.

Data collection process was organized in three stages - at a month before the learning and facilitating sessions, during the sessions, at the end of the sessions, and at a few months after the sessions being held. Data collection at the first stage involved document analysis (company annual reports, documented procedures and standards, electronic databases), at the second stage-audio-visual material (digital records of the process), the documented results, and audio records of the interviews in focus groups, at the third stage-interviews (transcripts of interviews between participants) and document analysis. Individuals involved in data collection process were senior and middle managers and key specialists of the company.

The case study analysis consists of four sections: the first section describes the research site and the problem; the second section outlines the first stage of the research based upon an audit of the current organizational model; the third section is devoted to a description of procedure facilitation with senior and top management on introducing IC theory; as a result of the analysis, following by reflection upon the changes occurred in the organization, is the topic of the fourth section.

\section{Case study findings}

The pilot IC processes to improve strategy, measurement, and management systems took place over a 3 month time span, including a total of seven workshops with the management team.

Firstly, the company needed to assess the level of the organization's management ability and readiness for introducing new strategic paradigm. Afterwards, the training with 44 participants (top and middle level managers and key specialists) was conducted to introduce the IC theory concept, Performance Management Framework, and Project Management standards.

The participants were divided into focus groups and started to develop organizational key strategic documents by reviewing company's mission, values, vision, and strategy. Afterward resource assessment and strategy mapping were performed. 
The research site and the problem

The mining company operates in the North Kazakhstan, and the mineral deposit is projected to last for 70 years. The company was established in 1965 and during Soviet Union period was state owned; in 1997, the company was privatized as most of others after Kazakhstan's independence. As a result of open sales the proprietor of the group of enterprises became a national investor. Currently, the mineral production of the company is supplied to more than 20 countries around the world. The capacity of the plant is sufficient to produce about 400.000 ton of mineral product annually and the number of employees is $\sim 3,500$. The company was acknowledged with international awards; ISO certified, mechanized, and automated.

During preliminary research, the targeted mining company was found conservative and resistant to changes. The reasons for this were peculiarities of historically determined mining business: the size of the company is relatively large; hierarchical structure and functional management are used; and clients are not sophisticated enough, in comparison with goods manufacturing companies. All of these features perfectly fit definition of a "mechanistic" organizations, which is considered in the business western literature out dated and ineffective. The traditional approach to mining management, which is strong hierarchical and non-flexible, emanates from the Soviet Union's hierarchical planned systems and is still performed through the CEO approving long-term, medium and short-term pit development plans, which are usually weakly related to the market demand (Tsekhovoy and Statsenko 2010). In emergent market economy, these traditional organizational structures and management practices largely geared to the mass production of ore of a certain quality for stable federal orders which are not adequate as they do not provide aligning the operational activity with the organizational strategy of the mining company. Moreover, the current situation has shown that the top leadership of the mining company do not fully realizes the necessity of systemic organizational change, trying to cope with significant challenges by means of backfired approaches such as cost cutting and staff reduction strategies.

\section{Resource assessment}

The company defined itself as a typical value chain, therefore, monetary and physical resources were considered as most valuable after the first iteration. A summary of the organizational resources is shown in the Appendix Table 1.

\section{Tangible resources}

For monetary resources traditional indicators were used as cash, investments, receivables, payables, compensation, and benefits as well as intangible indicators proposed by Roos et al. (2012). The analysis revealed that in spite of attracting investments and positive cash-flow, it is volatile and assets utilization is not effective.

The analysis of physical resources revealed that technological equipment capacity is enough, technological processes are standardized, however, modernization required. 


\section{Intellectual capital}

The IC profile was based on guidelines and indicators offered by Roos et al. (2012).

\section{Relational capital}

The analysis showed that the company had strong relationships with permanent customers and strong corporate responsibility, making economic and social impact to the community. However, the rising debates on harmful effects of mining for environment were needed to be taken into consideration. Another issue that required attention was the volatility of current consumption and measure to stabilize cash flow by acquiring new clients and developing new product line.

\section{Organizational capital}

A snapshot of the current simplified management model of the company is presented in Fig. 1.

The analysis revealed that the organizational capital needs the most initiatives to be put in practice as sufficient improvements are required. Although, operational activity was standardized by ISO 9001 specifications, project activity was not standardized. No structured process existed for the recording lessons learned, and the level of innovation was low. The company's performance measurement system included only financial and technological indicators, and there was no evidence of measuring intangible assets (see Fig. 2).

Organizational structure was hierarchical and rigid; there were problems with coordination between departments. Firstly, functional management "perceives the narrow picture from the perspective of silos". Secondly, there was a lack of "common language" among the functional silos. All the initiatives were perceived in different ways, which impeded the coordinated accomplishment of tasks set. The third problem was low trust among the employees to the top management decisions and between departments as well, which caused reluctance to change and low involvement with new initiatives.

\section{Human capital}

The analysis revealed that the number of managers familiar with modern strategic management practices was low. There was no shared understanding of company's strategy, therefore measures taken by senior management are not fully understood by employees; the basic qualified workforce was rather old; most of the middle level managers and specialists do not feel that their opinion was taken into consideration; just a small part of company's employees feel happy about the working environment.

There was competition among the departments, and knowledge sharing was common practice inside informal groups, but not between these groups. Managers of the departments take strict functional position. Some career promotions based on kinship harm employee motivation, and those without "relationships" are inspired by just the necessity to hold their position. 


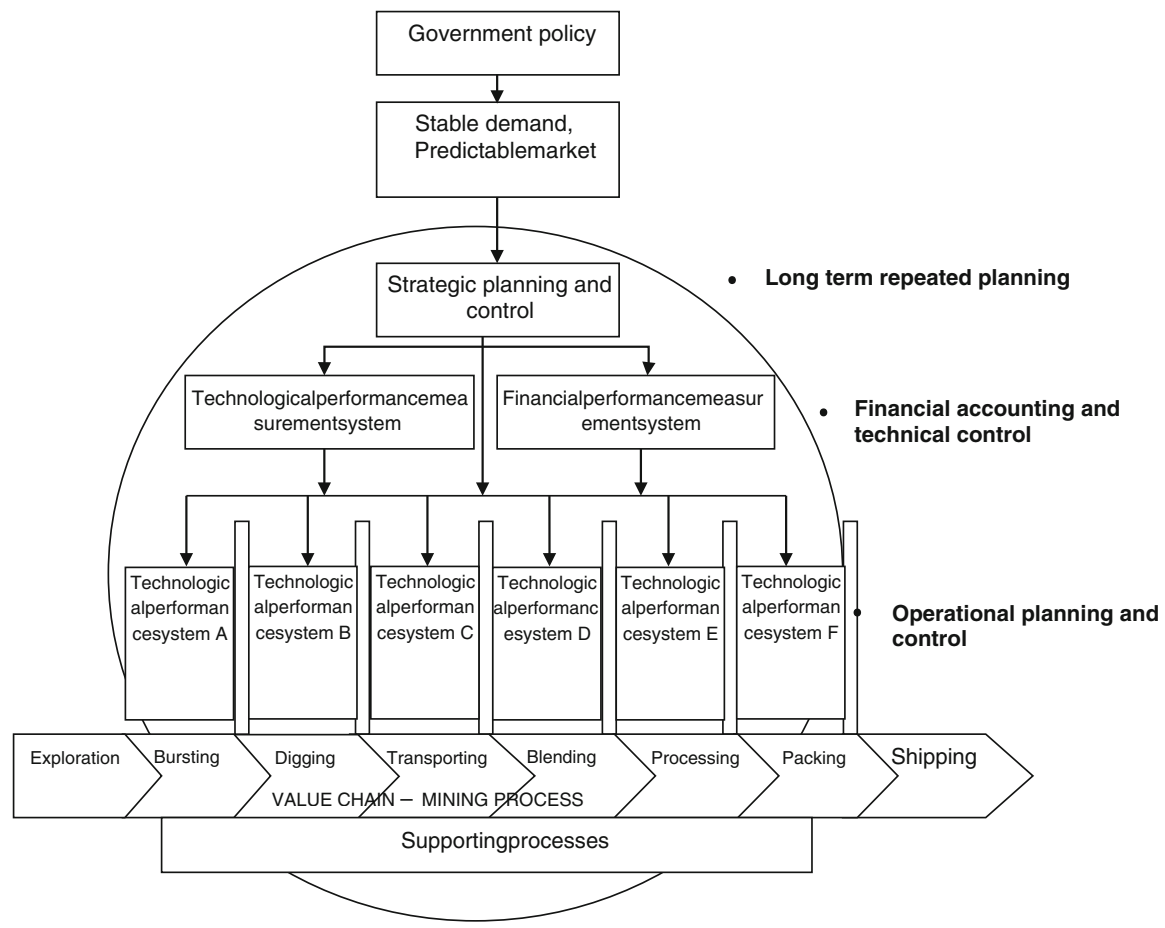

Fig. 1 Current management model of the mining organization. Note that this is hierarchical, and technological performance and financial performance are integrated only by the CEO

Performance measurement and management system development

The balanced scorecard approach to strategy mapping was introduced as a pattern for achieving strategic intent of the company. The four perspectives provide a framework for organizing strategic objectives, which are:

1. Financial perspective emphases shareholder satisfaction.

2. Customer perspective focuses on customer satisfaction, cost, etc.

3. Internal business processes outline strategic priorities;

4. Learning/growth of staff underpins the other three perspectives.

The learning and growth perspective as the ground of strategic map was developed, taking into consideration available resources. This trajectory encompasses the two strategic theories, Porter's (1981) competitiveness approach and resource- based view.

The first step taken by focus groups was developing the key strategic documents-mission, vision, values, and strategy of the company. Participants drew their perception of these key documents after what the groups presented to auditory. After refinement process the participants create the final versions of these documents. 


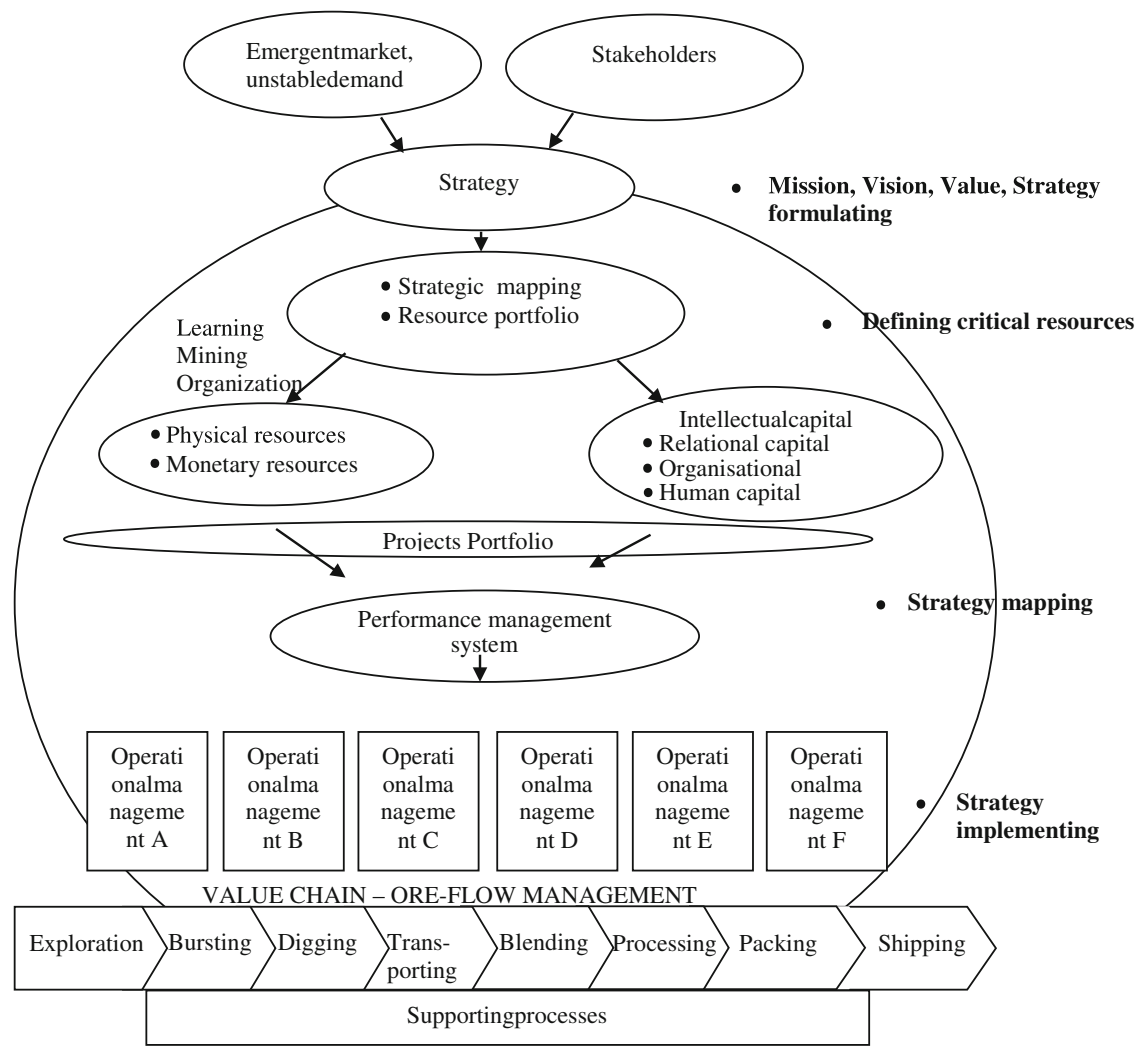

Fig. 2 The new model of management of learning mining organization

\section{Strategic map}

After the vision was clarified, the strategic goals for each of four perspectives were created to determine the way the organization intends to achieve these goals. The organization built a strategy map from the top to the down, starting from with strategic objective and charting the rout to it through all four perspectives.

Following Norton and Kaplan's (2007) approach, business stages and financial themes of the company were determined as "sustain", the business to maintain the existing market share and attract investments, but required it to earn excellent returns on capital.

The processes most critical for the organization strategy to succeed were identified. The business process management system was set as the main strategic goal. This should be achieved by improving company's standards for all business processes according to best practice. The second strategic goal was an internal perspective of optimizing the ore flow creation process, which should lead to customer satisfaction in the final product. The last strategic goal for the internal business perspective is increasing labor productivity and, as a result reducing the 
number of employees and improving cost structure by decreasing expenses. Innovations were determined as drivers for proposed improvements.

A strategic map of the company created by senior and middle level management, comprised of all four perspectives with cause-and-effect relationships, is shown in Fig. 3.

\section{Elaboration of the strategic goals, measures, targets and initiatives}

The next step was determining measures and targets for every goal. They were set during planning and connected with the mission and the vision of the company. For each measure, a number of strategic projects which were needed to achieve these goals were determined and chosen in a portfolio. The results of discussion of the working groups are presented in the Table 2, in the Appendix.

\section{Project management as strategy implementation tool}

While IC theory is useful for evaluating the role of intangible assets and critical resource distinction, and the BSC approach is a good tool to identify strategy formulation and cascading it to all levels of organization at this stage; the implementation of strategic initiatives and alignment with ongoing mining operational activities Project Management is a useful tool.

Projects are means of organizing activities that cannot be addressed within the organization's normal operational limits, they are usually utilized as means of achieving an organization's strategic plan and have been recognized as a primary strategy delivering instrument for over five decades (Kerzner 2013; Thompson et al. 2012; Unger et al. 2012).

However, during the first stage of the consultative sessions, the task of conducting cascading aims on structural departments of the company has not been established as well as the issue of implementing strategy through the set of initiatives. This issue requires future research.

\section{Conclusions and managerial implications}

The results and outcomes of the change management program were evaluated on the base of interviews, workshops with upper and middle management members, and by the use of performance indicators. The performance improvements were of quantitative nature like financial and process indicators as well as of qualitative nature like structural, organizational, and strategical enhancements. The following list gives an overview about the most important results.

During the consulting sessions, a framework, which could serve as a starting point for organizational transformation within transitional economy, was developed based on widely known western strategic management tools such as IC, BSC, and Project Management. It took into consideration peculiarities of local mentality and ways of doing business mostly related to the legacy of Soviet engineering and management school, which is far from market-based principles. In order to adopt 


\section{Financial}

Perspective

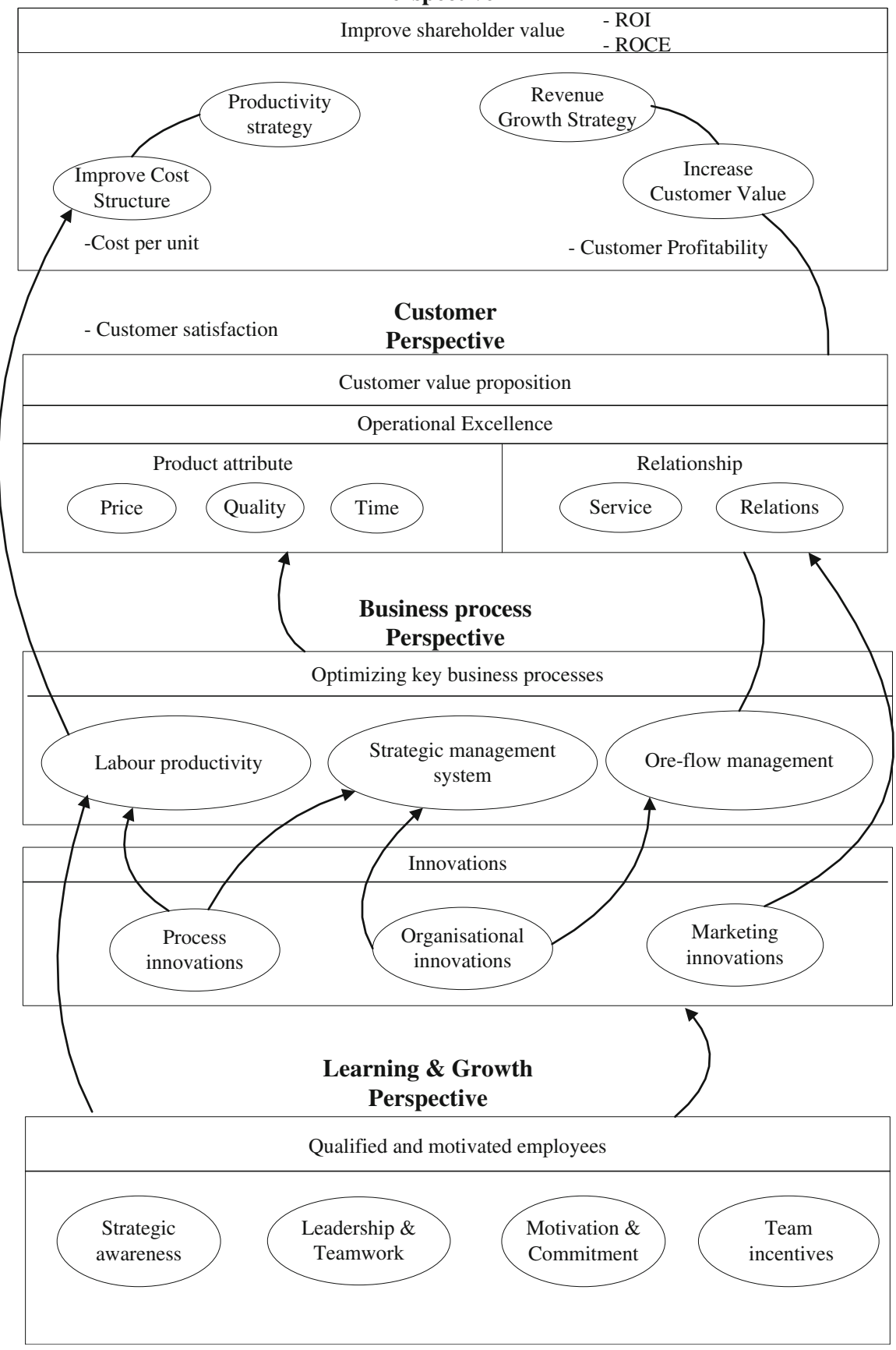

Fig. 3 Strategic map of mining company 
western approaches to the needs of Kazakh companies and to implement those approaches into the mining company specific training concepts and facilitating inhouse management teams were created. By using these new tools, it was possible to initiate and realize the change process and to overcome historic structures and mentalities.

One of the features of local strategic management was so-called "investment accountability attitude". Local mentality which determines the current attitudes of senior management team to investment accountability emanates from planned economy principles when the State accepted all risks. The USSR planned economy entirely controlled and managed mining industry capital. Thus, decision-making on investments into strategic initiatives was not transparent, established clearly and supported by sound procedures. Normally, it took autocratic form when all decisions were made by CEO and cascaded to lower levels.

Post-soviet mentality was also characterized by command-and-control attitude when lower levels performed unquestioned tasks. For example, it was noticed after a number of sessions that presence of CEO impedes creative thinking of the participants as they become frigid and passive. Even after being encouraged by CEO, they still felt confused to present their ideas. Thus, purposeful training and facilitating of strategic decision-making processes are required at the first stage of organizational transition. It was also noticed that presence of facilitator from tertiary organization-consultant-fostered brainstorming sessions.

Local strategic management practices were normally based on non-formalized empirical knowledge of senior management, which in most cases could not be presented in the form of quantitative assessment. Thus, the use of standardized knowledge management procedures and standards described in the Western literature was at its infancy stage. Lack of clear knowledge accumulation and transfer procedures for mining projects' organization put at risk their successful implementation and impede learning of new coming mining engineers and specialists being in line with the recommendations of Knox (2008).

Therefore, the introduced framework allowed addressing these deficiencies providing more open and transparent communications and a basis for establishment of strategic management procedures.

Another result of the research is newly developed organizational structure, which includes new Project Management Department which is responsible for strategic alignment of initiatives (projects) with company's strategy and operational activity. Tsekhovoy and Statsenko (2010) are supported in arguing that it is essential to improve management system as a whole through alignment with a strategy of the company. Project management is effective in supporting the process of implementing the developed strategic management model.

The newly created department is also responsible for standardisation and documentation of Project Management procedures, related to knowledge management. Implementation of standardized procedures for knowledge acquisition and storage, which provides the possibility for usage of "lessons learned", allowed to reduce risks in project assessment and implementation and, as a result, to increase efficiency of investments, which leads to financial benefits of the company. During post-implementation review, it was reported that established procedures of strategy 
formulating and communication using BSC and PM allowed to reduce the number of redundant managerial procedures, increased middle-level managers commitment and improved overall emotional climate in the organization.

Construct that IC is underpinned and driven by organizational trust and culture were proved-although employees possess the necessary skills and experience, the individual attitudes, which are the components of corporative culture and trust, should be aligned with the corporate goals. There appears to be support for Cabrita and Bontis (2008) view that general employee sentiment, which is a function of satisfaction, motivation, and commitment, positively affects collaboration and knowledge sharing process; training is indispensable as it leads to enhanced creativity; teamwork increases innovation and production. Thus, the issues of adjusting to market economy with the deficiency of strategic management skills and knowledge and, as a result, low efficiency of utilizing organizational intangible assets, which are likely to be very similar among the organizations in transitional post-soviet economies with slight variations related to particular context were addressed (Heliste et al. 2007; Kiessling et al. 2009).

The Balanced Score Card including strategic map was developed during training and facilitating sessions, which embraces and provides visual representation of company's strategy, tangible, and intangible assets. During this process, managers have learned new skills that will enable them to better understand the value of IC in the organization and force them to develop capabilities related to knowledge management. By utilizing these skills and understandings, better decisions about how IC can be utilized in particular organization settings will be made, which is in line with findings of other scholars (Dumay 2009) and this satisfies research question 1. Investing in employees (human capital) and infrastructure (organizational capital) affects the relational capital (Cabrita and Bontis 2008; Kaplan and Norton 2007), and therefore lead to the long term sustainable success of the organization. In spite of the fact that the role of intangible assets was recognized and managers understood how IC is constructed within the organization and how it linked to organizational financial performance, which addressed research question 2. Senior executives are now not only concerned about immediate return of investments made, but also a trial was made to quantify and visualize the effects of the "soft" investments on company's ROI.

Future research activities have to be done to embrace the following steps of restructuring the organization such as cascading scorecards to departments, establishing detailed policies of interdepartmental communication, developing the new policies of running projects in the organization, which require further exploration and the subject of another discussion. Further research activities will be oriented on the two following questions:

Is there support for the view that traditional IC frameworks oversimplify the complexity of intangible assets by trying to "fit" a specific context into one of the contemporary IC measurement frameworks rather than focus on the interrelation of intangible within this context (Dumay 2009; Ricceri and Guthrie 2009)?

How could the application of project management tools to implementing the strategic management model be improved in transitional CIS economies? 
This study has both theoretical and practical implications. It builds in theory by providing an insight on the role of IC theory, a construct, which is well established in the western management literature and may add to the previous works (Bukh and Johanson 2003; Cabrita and Bontis 2008; Dumay 2009; Edvinsson and Malone 1997; Edvinsson 2013; Kong 2008; Roos et al. 2012; Serenko et al. 2010; Sveiby 2003), in creating strategic oriented learning organization model within the context of a transitional post-soviet economy. This model could be useful for implementation in other large local companies previously operated using traditional mechanistic approaches.

It provides evidence that the weakest aspects of IC in today's Kazakh companies are structural and human capital. The organizational capital suffers from the lack of established strategic management process infrastructure. The new framework could be treated as a starting point of transforming the "mechanistic" organization to the "learning" one.

Finally, from a practical point of view, the study may be of interest to regulators and standard-setting bodies as it shed a light on the knowledge gap between the theoretically espoused benefits of IC and the reality of transitional economy organizational practices. So as a main message for the political level, the case study revealed that especially in post-soviet economies the improvement of the economic soft factors and structures are as important as the further development of the hard infrastructure for the future economic development.

\section{Appendix}

See Tables 1 and 2.

Table 1 Summary of resource assessment

\begin{tabular}{|c|c|c|c|}
\hline Resources & $\begin{array}{l}\text { Critical } \\
\text { resource }\end{array}$ & Current positive aspects & Weaknesses \\
\hline \multirow[t]{2}{*}{ Monetary } & $15 \%$ & Company supports positive cash flow & $\begin{array}{l}\text { Cost reduction required } \\
\text { Assets utilization is not effective enough }\end{array}$ \\
\hline & & Company attracts investments & Cash flow has been volatile recent 3 years \\
\hline \multirow[t]{3}{*}{ Physical } & $30 \%$ & $\begin{array}{l}\text { Technological equipment supply } \\
\text { enough capacity }\end{array}$ & Investments in modernization required \\
\hline & & The ore supplies are essential & $\begin{array}{l}\text { The necessity to find more effective and } \\
\text { sustainable way of production }\end{array}$ \\
\hline & & $\begin{array}{l}\text { Technological process is standardized } \\
\text { and well functioning }\end{array}$ & \\
\hline Relational & $25 \%$ & $\begin{array}{l}\text { Company has strong relationships } \\
\text { with permanent customers } \\
\text { Company has strong corporate social } \\
\text { responsibility }\end{array}$ & $\begin{array}{l}\text { Present industrial capability of mining } \\
\text { complex exceeds demand for the } \\
\text { company's production; therefore cutting } \\
\text { production cost strategy was put in } \\
\text { place } \\
\text { Debates with the Community on } \\
\text { harmfulness of mining }\end{array}$ \\
\hline
\end{tabular}


Table 1 continued

\begin{tabular}{|c|c|c|c|}
\hline Resources & $\begin{array}{l}\text { Critical } \\
\text { resource }\end{array}$ & Current positive aspects & Weaknesses \\
\hline \multirow[t]{9}{*}{ Organizational } & \multirow[t]{9}{*}{$15 \%$} & $\begin{array}{l}\text { The operational activity as core } \\
\text { business processes, standardized at } \\
\text { operational level by ISO } 9001\end{array}$ & $\begin{array}{l}\text { The performance measurement system of } \\
\text { the company included only financial and } \\
\text { technological indicators; }\end{array}$ \\
\hline & & $\begin{array}{l}\text { The IT infrastructure provides the } \\
\text { capability for effective knowledge } \\
\text { sharing }\end{array}$ & $\begin{array}{l}\text { There is no integrated performance } \\
\text { management which includes intangible } \\
\text { assets measurement and management; }\end{array}$ \\
\hline & & \multirow[t]{7}{*}{$\begin{array}{l}\text { Company has awards for operational } \\
\text { excellence }\end{array}$} & $\begin{array}{l}\text { Project activity is not standardized- } \\
\text { nitiatives performed by non-formalized } \\
\text { procedures and mixed techniques. } \\
\text { Therefore, the success of initiatives } \\
\text { taken is not possible to measure and } \\
\text { there were not any structure }\end{array}$ \\
\hline & & & $\begin{array}{l}\text { No structured storage for "lessons } \\
\text { learned" information in the intranet for } \\
\text { sharing knowledge within the } \\
\text { organization }\end{array}$ \\
\hline & & & $\begin{array}{l}\text { All R\&D projects in the company are } \\
\text { focused on improvements of separate } \\
\text { technological processes and there is not } \\
\text { any holistic system which integrates and } \\
\text { aligns this improvements with the } \\
\text { organizational strategy, }\end{array}$ \\
\hline & & & $\begin{array}{l}\text { The level of innovation is low, company } \\
\text { does no acquire patents recently }\end{array}$ \\
\hline & & & $\begin{array}{l}\text { Organizational structure is hierarchical } \\
\text { and rigid, there are problems with } \\
\text { coincidence between departments }\end{array}$ \\
\hline & & & $\begin{array}{l}\text { Employee participation in improvements } \\
\text { is quite low }\end{array}$ \\
\hline & & & $\begin{array}{l}\text { Investments in product and process } \\
\text { development are not enough }\end{array}$ \\
\hline \multirow[t]{5}{*}{ Human } & \multirow[t]{5}{*}{$15 \%$} & $\begin{array}{l}\text { The organizational staff possess } \\
\text { technological knowledge } \\
\text { Company invests in employee } \\
\text { development and training programs }\end{array}$ & $\begin{array}{l}\text { There is no shared understanding of } \\
\text { company's strategy, therefore measures } \\
\text { taken by senior management are not } \\
\text { fully understood by employees; }\end{array}$ \\
\hline & & Skilled personal present $80 \%$ & The basic qualified workforce is rather old \\
\hline & & $\begin{array}{l}40 \% \text { of top management hold } \mathrm{PhD} \\
\text { degree }\end{array}$ & $\begin{array}{l}\text { The middle level managers do not possess } \\
\text { strategic management skills }\end{array}$ \\
\hline & & Staff turnover is up to $10 \%$ & $\begin{array}{l}10 \% \text { of staff feel that their opinion is } \\
\text { taken into consideration }\end{array}$ \\
\hline & & & $\begin{array}{l}20 \% \text { of staff feel happy about the } \\
\text { working environment }\end{array}$ \\
\hline
\end{tabular}









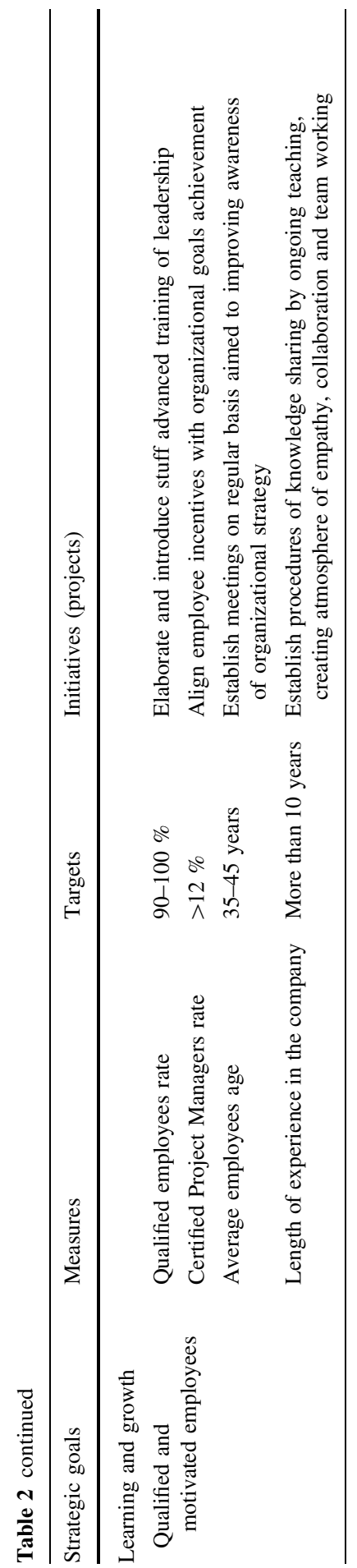




\section{References}

Alymkulova, A., \& Seipulnik, D. (2005). NGO strategy for survival in central Asia: Financial sustainability. The William Davidson Institute, Policy Brief No. 22.

Amit, R., \& Schoemaker, P. J. (1993). Strategic assets and organizational rent. Strategic Management Journal, 14(1), 33-46.

Andekina, R., \& Medeni, T. (2013). Knowledge management in accounting for firms: Best practices and learning lessons for Kazakhstan. International Journal of eBusiness and eGovernment studies, 5(2), $122-132$.

Andreeva, T., \& Kianto, A. (2012). Does knowledge management really matter? Linking knowledge management practices, competitiveness and economic performance. Journal of Knowledge Management, 16(4), 617-636.

Barney, J. (2001). Resource-based theories of competitive advantage: A ten-year retrospective on the resource-based view. Journal of management, 27(6), 643-650.

Beer, M., \& Mike, B. (2013). Footprints in the sand (Michael Beer). Organizational Dynamics, 42(4), 307-313.

Bhasin, M. (2012). Measurement and disclosure of intellectual capital in a developing country: An exploratory study. Australian Journal of Business and Management Research, 52(8), 63-75.

Bhuiyan, S. (2011). Transition towards a knowledge-based society in post-communist Kazakhstan: Does good governance matter? Journal of Asian and African Studies, 46(4), 404-421.

Bogko L. (2012) Initiating and developing industrial-innovation infrastructure at border areas. Management issues, UrAS, 1(3), 52-57 (in Russian).

Briner, R. B., Engwall, L., Juillerat, T. L., Mintzberg, H., Morgeson, F. P., Pratt, M. G., et al. (2012). Bridging the management theory and practice gap. In S. Tengblad (Ed.), The work of managers: Towards a practice theory of management (p. 318). New York, NY: Oxford University Press.

Bruton, G., Ahlstrom, D., \& Obloj, K. (2008). Entrepreneurship in emerging economies: Where are we today and where should the research go in the future. Entrepreneurship theory and practice, 32(1), $1-14$.

Bukh, P., \& Johanson, U. (2003). Research and knowledge interaction: Guidelines for intellectual capital reporting. Journal of Intellectual Capital, 4(4), 576-587.

Cabrita, M., \& Bontis, N. (2008). Intellectual capital and business performance in the Portuguese banking industry. International Journal of Technology Management, 43(1), 212-237.

Conner, K. R., \& Prahalad, C. K. (1996). A resource-based theory of the firm: Knowledge versus opportunism. Organization science, 7(5), 477-501.

Creswell, J. (2007). Qualitative inquiry \& research design: Choosing among five approaches. Thousand Oaks, CA: Sage Publications Inc.

Dosmanbetova, M. (2013). Analysis of intellectual capital development in Kazakhstan's corporations. Actual problems of Economics, 136, 410-417.

Dumay, J. (2009). Intellectual capital measurement: A critical approach. Journal of Intellectual Capital, 10(2), 190-210.

Dyker, D. (2005). Technological change, network building and dynamic competitiveness in the engineering industry in Kazakhstan. Post-Communist Economies, 17(4), 485-501.

Edvinsson, L. (2013). IC 21: reflections from 21 years of IC practice and theory. Journal of Intellectual Capital, 14(1), 163-172.

Edvinsson, L., \& Malone, M. (1997). Intellectual capital: Realizing your company's true value by finding its hidden brainpower. New York: Harper Business.

Grant, R. M. (1996). Toward a knowledge-based theory of the firm. Strategic Management Journal, 17, 109-122.

Griffith, D., Zeybek, A., \& O’Brien, M. (2001). Knowledge transfer as a means for relationship development: A Kazakhstan-foreign international joint venture illustration. Journal of International Marketing, 9(2), 1-18.

Guba, E., \& Lincoln, Y. (1994). Competing paradigms in qualitative research. Handbook of qualitative research, 34(2), 163-194.

Helfat, C., \& Peteraf, M. (2003). The dynamic resource-based view: Capability lifecycles. Strategic Management Journal, 24(10), 997-1010. 
Heliste, P., Karhunen, P., \& Kosonen, R. (2007). Foreign investors as agents of organizational change in transition economies: Human resource management practices of finnish firms in Estonia. EBS Review, 22, 16.

Hoskisson, R., Wright, M., Filatotchev, I., \& Peng, M. (2013). Emerging multinationals from mid-range economies: The influence of institutions and factor markets. Journal of Management Studies, 50, 1295-1321.

Illyashenko, S. \& Shypulina, Y. S. (2013). A role and task marketing of knowledge on the modern stage of economic development. Retrieved September 9, 2013 from http://www.essuir.sumdu.edu.ua/ bitstream/123456789/31552/1/Marketing_of_\%20knowledge_Illyashenko.pdf.

Ireland, R., \& Webb, J. (2009). International entrepreneurship in emerging economies: A resource-based perspective. Entrepreneurial strategies: New technologies in emerging markets (p. 47). Malden, MA: Wiley.

Ismail, K. M., Ford, J., Wu, Q., \& Peng, M. (2013). Managerial ties, strategic initiatives, and firm performance in Central Asia and the Caucasus. Asia Pacific Journal of Management, 28, 1-14.

Kabdiyeva, A. (2013). Developing sustainable NGOs in Kazakhstan. Asian Social Science, 9(7), 299.

Kaplan, R., \& Norton, D. (2007). Using the balanced scorecard as a strategic management system. Harvard Business Review, 85(7-8), 150-161.

Kerzner, H. R. (2013). Project management: A systems approach to planning, scheduling, and controlling. Hoboken, NJ: Wiley.

Kholjigitov, G. A. (2013). On the issues of reforming pension system in emerging economies: Case on the Republic of Kazakhstan. Available at SSRN.

Kianto, A., Andreeva, T., \& Pavlov, Y. (2013). The impact of intellectual capital management on company competitiveness and financial performance. Knowledge Management Research \& Practice, 11(2), 112-122.

Kiessling, T. S., Richey, R. G., Meng, J., \& Dabic, M. (2009). Exploring knowledge management to organizational performance outcomes in a transitional economy. Journal of World Business, 44(4), 421-433.

Knoop, T. (2013). Global finance in emerging market economies. New York: Routledge.

Knox, C. (2008). Kazakhstan: Modernizing government in the context of political inertia. International Review of Administrative Sciences, 74(3), 477-496.

Kong, E. (2008). The development of strategic management in the non-profit context: Intellectual capital in social service non-profit organizations. International Journal of Management Reviews, 10(3), 281-299.

Kraaijenbrink, J. (2009). High-tech small-and medium-sized enterprises: Methods and tools for external knowledge integration. New Technology-Based Firms in the New Millenium, 7, 117-129.

Martín-de Castro, G., Delgado-Verde, M., Amores-Salvadó, J., \& Navas-López, J. E. (2013). Linking human, technological, and relational assets to technological innovation: Exploring a new approach. Knowledge Management Research \& Practice, 11(2), 123-132.

Medved, M., Malenkovic, V., \& Dervaric, E. (2011). Restructuring of the coal mining enterprises in Slovenia. Technics Technologies Education Management, 6(2), 247-255.

Peteraf, M. (1993). The cornerstones of competitive advantage: A resource-based view. Strategic Management Journal, 14(3), 179-191.

Petty, R., \& Guthrie, J. (2000). Intellectual capital literature review: Measurement, reporting and management. Journal of Intellectual Capital, 1(2), 155-176.

Porter, M. E. (1981). The contributions of industrial organization to strategic management. Academy of Management Review, 6(4), 609-620.

Priem, R., Butler, J., \& Li, S. (2013). Toward reimagining strategy research: Retrospection and prospection on the 2011 AMR decade award article. Academy of Management Review.

Quast, L. (2012). Why knowledge management is important to the success of your company. Retrieved September 7, 2013 from http://www.forbes.com/sites/lisaquast/2012/08/20/why-knowledgemanagement-is-important-to-the-success-of-your-company.

Radosevic, S., \& Myrzakhmet, M. (2009). Between vision and reality: Promoting innovation through technoparks in an emerging economy. Technovation, 29(10), 645-656.

Ricceri, F., \& Guthrie, J. (2009). Critical analysis of international guidelines for the management of knowledge resources. Padua: University of Padova.

Roos, G., Pike, S., \& Fernstrom, L. (2012). Managing intellectual capital in practice. London: Routledge. Savitt, R. (1998). Management practices in Czech Republic: Restructuring and market orientation. Journal for East European Management Studies, 4, 339-354. 
Serenko, A., Bontis, N., Booker, L., Sadeddin, K., \& Hardie, T. (2010). A scientometric analysis of knowledge management and intellectual capital academic literature (1994-2008). Journal of Knowledge Management, 14(1), 3-23.

Statsenko, L., Ireland, V., \& Tsekhovoy, A. (2013). Case study of applying intellectual capital theory for accelerating innovations in Kazakh mining company. doi:10.5593/SGEM2013/BE5.V2/S23.003.

Stewart, T., \& Ruckdeschel, C. (1998). Intellectual capital: The new wealth of organizations. Performance Improvement, 37(7), 56-59.

Sveiby, K. (2003). How (and why) did the field of knowledge management come into being? Ekonomiska samfundets tidskrift, 56(3), 185-188.

Thompson, A., Peteraf, M., Gamble, J., \& Strickland, A, I. I. I. (2012). Crafting and executing strategy: The quest for competitive advantage: Concepts and cases. Irwin: McGraw-Hill.

Thorpe, R., Holt, R., Macpherson, A., \& Pittaway, L. (2005). Using knowledge within small and mediumsized firms: A systematic review of the evidence. International Journal of Management Reviews, $7(4), 257-281$.

Tsekhovoy, A., \& Statsenko, L. (2010). The role of project management standards in mining management systems. Kazakhstan Mining Journal, 11(11), 5-9.

Unger, B., Kock, A., Gemünden, H., \& Jonas, D. (2012). Enforcing strategic fit of project portfolios by project termination: An empirical study on senior management involvement. International Journal of Project Management, 30(6), 675-685.

Wernerfelt, B. (1984). A resource-based view of the firm. Strategic Management Journal, 5(2), 171-180.

World Economic Forum, C. f. G. C. a. P. (2013). Global competitiveness report 2012-2013, Geneva, Switzerland. Retrieved June 2, 2013 from http://www3.weforum.org/docs/WEF_ GlobalCompetitivenessReport_2012-13.pdf.

Zabortseva, Y. (2009). A structural approach to diversification of the emerging economy of Kazakhstan. International Journal of Economic Policy in Emerging Economies, 2(1), 23-40. 